\title{
Study on the cells development of Enteromorpha prolifera on conditions of DC field
}

\author{
Yuhang Zheng \\ North China Electric Power University, Beijing 102206, China \\ aharvardchaser@163.com
}

Keywords: Enteromorpha, single cell, production, electric field.

\begin{abstract}
To study the effects of DC field on development of the cells in Enteromorpha prolifera, We get single cell of Enteromorpha prolifera by the method of enzymolysis and after giving them the stimulation of electric field, cells development show up three directions: 1, producing with obvious polarity, the cell extends to one end and produces to the Single-celled seeding with rhizoid directly; 2, combine into callus and become new seedlings later; 3, remain stable and undevelop. Enteromorpha prolifera cells during development are very sensitive to electrical stimulation and development direction and chlorophyll content depend largely on different intensities meanwhile the number of Enteromorpha prolifera cells depend on the dissociation degree. The result shows that the range of $10 \sim 150 \mu \mathrm{A} \cdot \mathrm{cm}-2 \mathrm{DC}$ field helps to the generation of Single-celled seedlings.
\end{abstract}

\section{Introduction}

Enteromorpha prolifera belongs to Chlorophyta, Chlorophyceae, Ulvales, Ulvaceae, and Enteromorpha, which is widely distributed in the Chinese coastline. Because the marine organism is very sensitive to growing environment, the small changes in the marine environment can result in the explosive growth of some dominant species [1-2]. The population explosion of Enteromorpha prolifera have a similar effect on marine fishes and other marine organism as red tide [3].

The contaminants and pollutant are the main environmental factors which effect the growth of Enteromorpha prolifera. In the marine environment, the animal factors and typhoon also have some effects on Enteromorpha prolifera. Enteromorpha prolifera has a strong ability to reproduce and there many researches on the sporogony of Enteromorpha prolifera. In terms of Enteromorpha prolifera cultivation, under natural conditions, Enteromorpha compressa and Enteromorpha intestinalis's button can form the rhizoid and the top form the thallus. Someone is inspired by the phenomenon to cut the nutrition thallus of Enteromorpha prolifera into small pieces and obtain the germ cells [4-5]. Researches show that the cells have polarity which determines the reproduction's direction in the progress of Enteromorpha prolifera's regeneration [2-6]. We use the means of enzymolysis to get Enteromorpha prolifera's single cell and research development of single-celled seedlings by electric field stimulation.

\section{Materials and methods}

\subsection{Materials}

E. intestinal is, which are delicate individuals, washed by sterilized water after collected.

Adjustable DC power supply (Jintan Rulin Electronic Instrument Factory); climatic cabinate (Sinopharm Group Guangdong sheng Medical Equipment Co, Ltd); fluorescence spectrometer (Japan).

\subsection{Reagent}

Monodonta labio. The Conch enzyme is collected in digestive gland of monodonta labio. Cellulase (enzyme activity $4 \times 104{\mathrm{u} . \mathrm{g}^{-1}}^{\text {) }}$ and pectase (enzyme activity $4 \times 104 \mathrm{u} . \mathrm{g}^{-1}$ ).

\subsection{Methods}

Enzymic preparations. Wash the conch and kept in sterilized sea water for 2 or 3 days and then remove the digestive glands. Put the digestive glands in mortar with quartz sand and sea water, 
ground to a paste, keep static, drain the supernatant, and Refrigerated centrifuge the supernatant for $30 \mathrm{~min}$ by $12000 \mathrm{rmin}^{-1}$. Take the supernatant and centrifuge it for three times to get enzyme. Use 0.2 mol.L ${ }^{-1}$ Phosphate Buffered Saline to make up cellulase solution, pectinase solution and conch enzyme solution.

Preprocessing of algae. Choose the algae without generative cell by microscopy and then wash the algae by sterile seawater repeatedly until no other types of algae. Use $0.7 \%$ liquor kalii iodide to make surface sterilization for 5 10min. Rinse the algae for three times by 0.7 mol. $\mathrm{L}^{-1}$ sodium chloride solution in order to remove residual potassium iodide. Cut the algae into pieces of $2.0 \times 2.0 \mathrm{~mm}$.

Enzymatic Hydrolysis Experiment. Accurately weigh the algae pieces for 1g. Put in $2 \mathrm{~mL}$ of $1 \%$ volume of liquid mixture of cellulose solution and conch enzyme solution [7-8], and 5M glucose solution. Get precipitate cells after reaction and wash it with sterile seawater three times to remove the enzyme.

Cultured cell. Put the prepared single cells in square culture bottle which has sterile seawater with $2 \mathrm{mg.} \mathrm{L}^{-1}$ germanium dioxide. The environmental elements are: PH7.0, Photoperiod L: $\mathrm{D}=12: 12$, Light intensity $2500 \mathrm{~lx}$, Temperature $20^{\circ} \mathrm{C}$. Counting cells before culture them and diluted living cells with culture medium.

Electrical stimulation of cells and determination of chlorophyll. The first day of cell culture, applying electric fields with different intensity on the cells. The gradients are $0 \mu \mathrm{A} . \mathrm{cm}^{-2}, 50 \mu \mathrm{A} . \mathrm{cm}^{-2}$, $100 \mu \mathrm{A} . \mathrm{cm}^{-2}, 150 \mu \mathrm{A} . \mathrm{cm}^{-2}, 200 \mu \mathrm{A} . \mathrm{cm}^{-2}$, and $250 \mu \mathrm{A} . \mathrm{cm}^{-2}$. Electrodes are titanium electrode (apparent area: $3 \mathrm{~cm} \times 3 \mathrm{~cm}$, real area: about $180 \mathrm{~cm}^{2}$ ) and gauze platinum electrode (apparent area: $3 \mathrm{~cm} \times 3 \mathrm{~cm}$, real area: about $48 \mathrm{~cm}^{2}$ ) [9]. Observing and taking photos while culturing, the culturing lasts for 7days. Using fluorescence spectrophotometer to measure the content of chlorophyll [10], motivating at $430 \mathrm{~nm}$, lasing at $663 \mathrm{~nm}$ and use $90 \%$ acetone as control group.

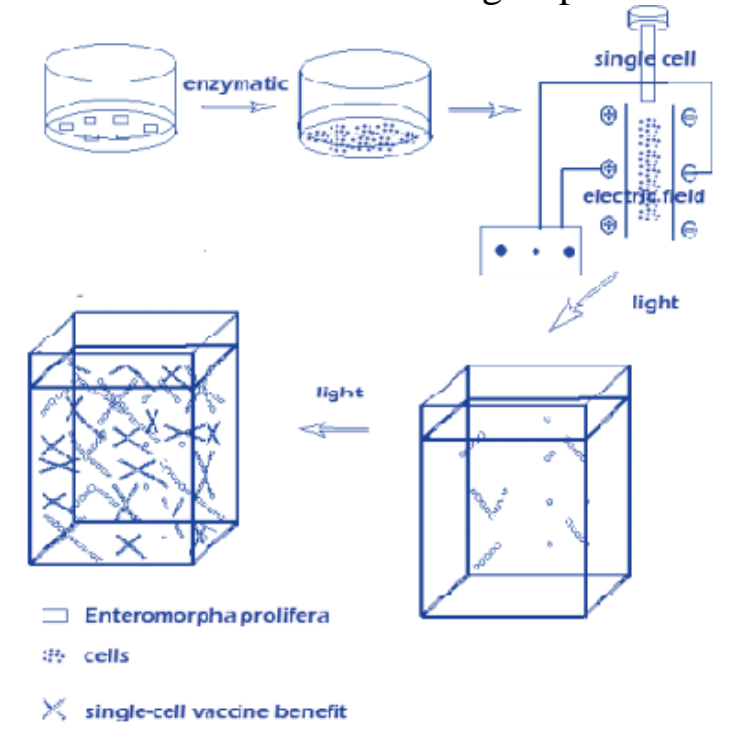

Figure 1. Flow chart of enzymolysis, electrical field stimulation and light culture on frond fragments

\section{The results and analysis}

\subsection{Treatment of algal fragments}

Filtering and collecting the single cell after enzyme treatment. Applying electric fields and then treat the living cells with light culture.

\subsection{Results of enzymatic hydrolysis}

Use $1 \%$ cellulose solution and conch enzyme solution in turn to make enzymolysis analysis. The edge of algal fragments become flexible and a small amount of global protoplast and single cells with irregular shape drift away. The pectase enzyme has no obvious effect on algal fragments. In order to get better enzymolysis we use cellulose solution and conch enzyme solution together and design the orthogonal experiment to find the best experimental conditions: $\mathrm{pH} 6.6,25^{\circ} \mathrm{C}, 2 \mathrm{~h}$. 


\subsection{Effects of hydrolysis temperature on the survival rate of Enteromorpha prolifera cells}

Temperature is the main factor of cell dissociation. The higher the temperature the better the enzyme-effect is. But the too high temperature will limit the cytoactive because the cells will easily disrupt and loss chromatoplast and both of them will affect the cell viability. The figure 2 shows that the single cell viability is high in $10 \sim 25^{\circ} \mathrm{C}$ and the cell viability drop fast when the temperature is higher than $25^{\circ} \mathrm{C}$. So the Enteromorpha prolifera's cell viability can be kept when the temperature is higher than $25^{\circ} \mathrm{C}$.

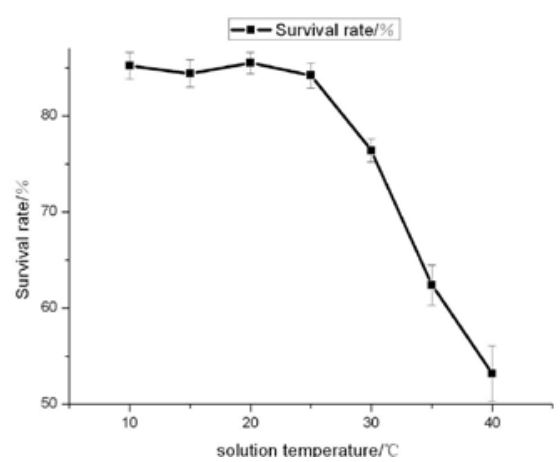

Figure2. The amount change of inter-relationship between Reaction temperature and Enteromorpha prolifera survival rate of single-cell

\subsection{The effect of electric fields with different intensity on chlorophyll content.}

Use titanium electrode as positive electrode and gauze platinum electrode as negative electrode. The experimental current density are $10 \mu \mathrm{A} . \mathrm{cm}^{-2}, 50 \mu \mathrm{A} . \mathrm{cm}^{-2}, 100 \mu \mathrm{A} . \mathrm{cm}^{-2}, 150 \mu \mathrm{A} . \mathrm{cm}^{-2}, 200 \mu \mathrm{A} . \mathrm{cm}^{-2}$, and $250 \mu \mathrm{A} . \mathrm{cm}^{-2}$. The result is in figure $3(\mathrm{n}=6)$.

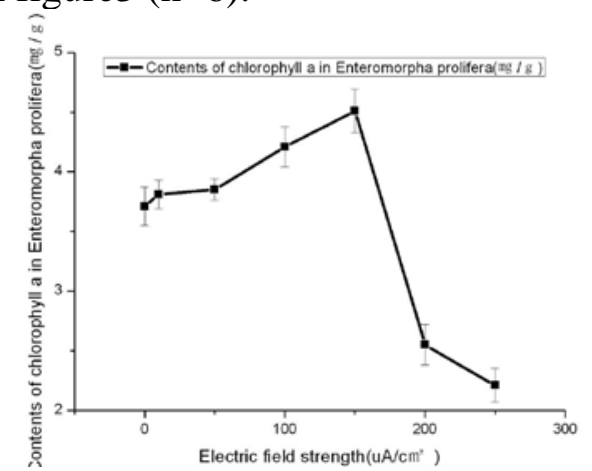

Figure 3.The amount of change between DC electric field intensity and the number of Enteromorpha prolifera chlorophyll relationship

The content of chlorophyll a reflects the growth of Enteromorpha prolifera [11] and is related to development stage. The content of chlorophyll is the important reason that rapid increase in biomass, so it can be treated as the index which reflects the development status of Enteromorpha prolifera. As shown in the figure3, with the increase of current intensity, the concentration of chlorophyll a first increases and then decreases. Within 10 150 $\mathrm{AA} . \mathrm{cm}^{-2}$, the electrical field stimulation is beneficial to the growth of Enteromorpha prolifera. When the electric field strength is greater than $150 \mu \mathrm{A} . \mathrm{cm}^{-2}$, the growth of Enteromorpha prolifera will be limited [9].

It shows that the large current density will kill the algal cells. And the exchange of anode and cathode doesn't change the conclusion which means titanium, platinum and Enteromorpha cell can be compatible.

\subsection{The development process of Enteromorpha prolifera cell with DC electric field}

The Enteromorpha single cells have three development directions under DC electric field: Cells appeared obvious polarity and reproduce in one direction. Have a structure similar to the rhizoid and finally become the single cell vaccine with rhizoid; Single cells form multicellular and develop into seedlings; Cells keep the original state.

Single cell vaccine produce polarization phenomenon first. The chromophores gather upward. At the bottom, cytoplasm extends outwards to have a structure similar to the rhizoid. On the top, cells 
split into string and finally become a single cell vaccine. (Picture I5, 6, 7, 8) In experiments we found that Enteromorpha prolifera blooms in the way of Single-celled plants. Under the condition of $10 \sim 150 \mu \mathrm{A} . \mathrm{cm}^{-2}$ of the electric field, the developmental single-celled plants accounted for more than $90 \%$ of the total seedlings. (Picture 4 )

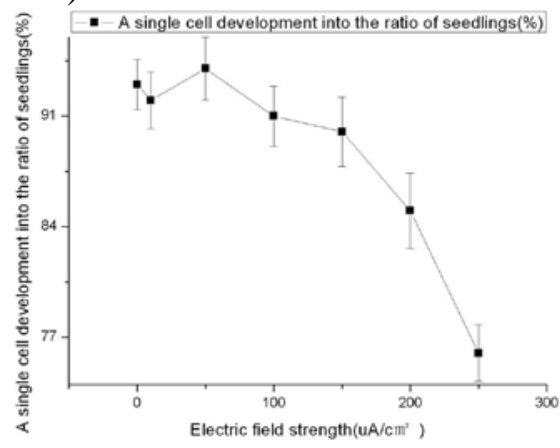

Figure 4. The ratio of single-celled seedlings in different strength of dc field stimulation by a single cell development produce

Multicellular plants form multicellular clusters thought cell division and then form new Enteromorpha. (Picture I9, 10, 11, 12, 13, 14) In the specific growth process, multicellular cells often form single or multiple columns of cells first and then then become proteome. Cell differentiation rate related to the size of the cells. When the applied electric field is greater than $150 \mu \mathrm{A} . \mathrm{cm}^{-2}$, single cell gathered form cell mass easily which is particularly obvious in $72 \mathrm{~h}$. When the applied electric field is less than $150 \mu \mathrm{A} . \mathrm{cm}^{-2}$, a small number of single cells appear gathered phenomenon and only few cells can form cell mass.

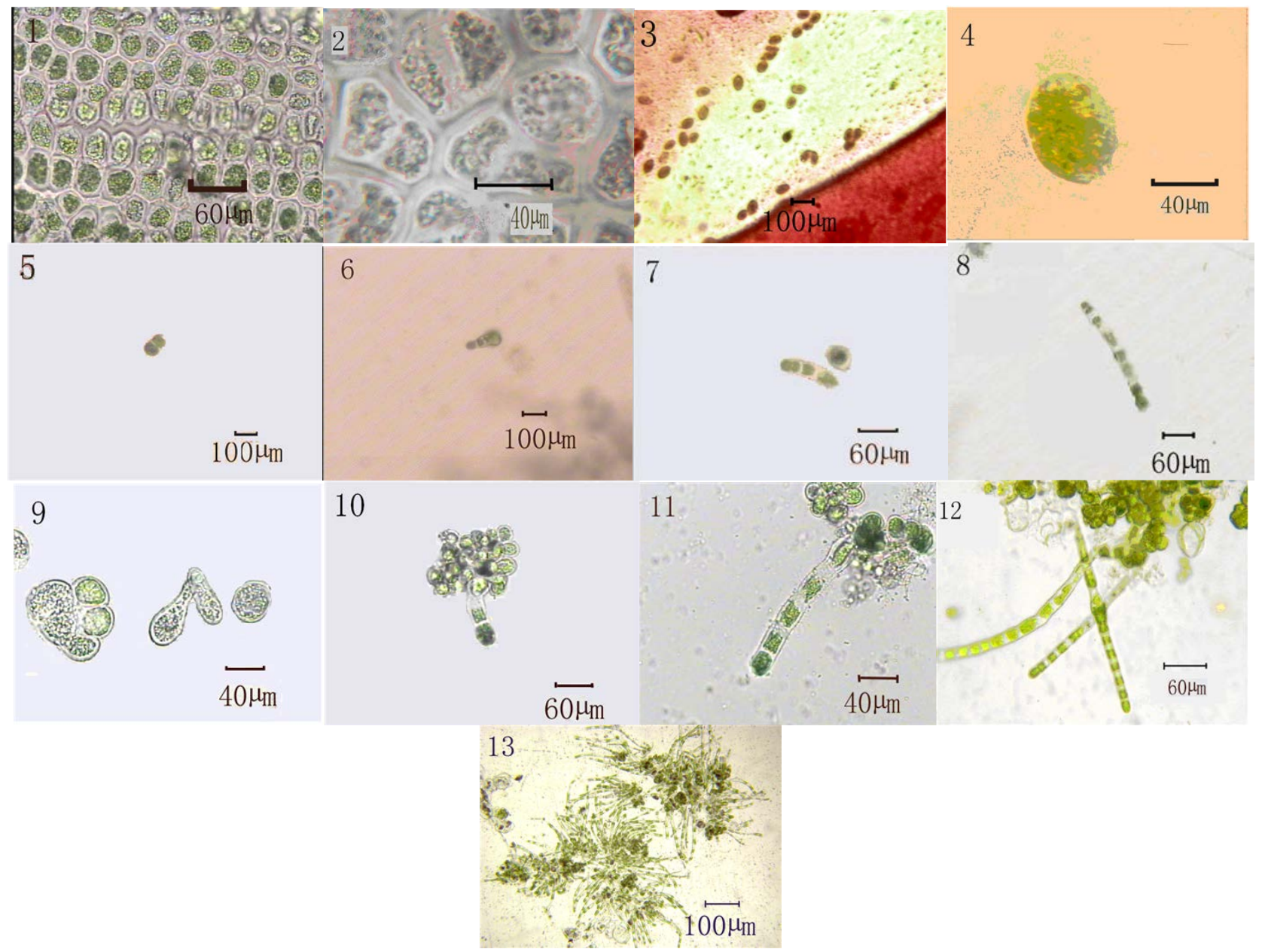

Leafy and flaky Somatic of Enteromorpha prolifera in Figure 1, 2. Single cell of Enteromorpha prolifera by composite enzymatic hydrolysis in Figure 3, 4. Single cell of Enteromorpha prolifera produces into filament (Single-celled seeding) after Electrical Field Stimulation. Figure 5 says the double cells period on the second day of the culture period, in which the cell appears Polarity 
differentiation. Figure 7 says the four cell period on the third day of the culture period. Figure 8 says the eight cells period. Single cell of Enteromorpha prolifera produces into filament (multicellular seedlings) after Electrical Field Stimulation. Figure 9 says the condition of single cell aggregation and development. Figure 10 says the cell mass produce to seeding. Figure 10-13 say that the developmental state of multicellular seedlings as culture time goes on.

\section{Conclusion}

Enteromorpha prolifera by composite enzymatic hydrolysis can generate a lot of single-celled plants after light culture. Enteromorpha cell nomadic situation and cell vitality are different under different enzymatic hydrolysis conditions which directly affect the viability of Enteromorpha cells. $10 \sim 150 \mu \mathrm{A} . \mathrm{cm}^{-2}$ DC field is conducive to form single-celled plants. When DC field is bigger than $150 \mu \mathrm{A} . \mathrm{cm}^{-2}$, Enteromorpha cell growth will be suppressed and gathered to form multicellular plants. The development condition of Enteromorpha single-celled plants has certain theoretical and practice meaning to reveal the multiplication of Enteromorpha biomass and provides a new way of thinking of the explosive growth of Enteromorpha mechanism under the environment of thunder and lightning.

\section{References}

[1] Xia B, Ma S, Cheng J, et al. Distribution of organic carbon and carbon fixed strength of phytoplankton in Enteromorpha prolifera outbreak area of western south yellow sea,2008 [J]. Environmental Science, 2010, 31 (6), 1442-1449.

[2] Thyssen M, Mathieu D, Garcia N, et al. Short-term variation of phytoplankton assemblages in Mediterranean coastal waters recorded with an automated submerged flow cytometer [J]. Journal of Plankton Research, 2008, 30 (9), 1027-1040.

[3] Ye N, Zhang X, Mao Y, et al. 'Green tides' are overwhelming the coastline of our blue planet: taking the world’s largest example[J]. Ecological Research, 2011, 26(3): 477-485.

[4] Liu Y, Chang X, Wang G, et al. Harm and prevention of Enteromorpha prolifera [J]. Journal of Anhui agricultural sciences, 2009, 37(20):9566 9567.

[5] Lee T F, Wichroski M. Polar regeneration in Enteromorpha prolifera [J]. J Phycol, 1996, 32: 2.

[6] Dan A, Ohno M, Matuoka M. Cultivation of the green alga Enteromorpha prolifera using chopped tissue for artificial seeding [J]. Suisan zoshoku, 1997, 45:5-8.

[7] Dan A, Hiraokam M, Ohno M, et al. Observations on the effect of salinity and photon fluence rate on the induction of sporulation and rhizoid formation in the green alga Enteromorpha prolifera [J]. Fisheries Science, 2002, 68:1182-1188.

[8] Han B, Liu W, Wang H, et al. Studies on the enzymes of algal cell wall hudrolysis [J]. Marine Sciences, 1997, 21(3):47-49.

[9] Xu X, Wang P, Zhao S. Study on the tool enzymes of isolating protoplasts of porphyra yezoensis [J]. Journal of Huaihai institute of technology (Natural sciences edition), 2007, 16(3):66-69.

[10] Ma J, Sen X, Liu B, et al. Study on the electrolytic stimulation mechanism of Escherichia coli by a direct current [J]. Chemistry Online, 2010, 2:252-256.

[11] Jiang X. Determination of chlorophyll-an in surface water by fluorophotometry [J]. Modern Scientific Instruments, 2009, 1:79-80. 